\title{
Modulation of Chloroquine in nanoparticle uptake: a review
}

\author{
Modulação da Cloroquina na captação de nanopartícullas: uma revisão \\ Modulación de la cloroquina en la captura de nanopartículas: una revision
}

Recebido: 11/10/2021 | Revisado: 16/10/2021 | Aceito: 20/10/2021 | Publicado: 22/10/2021

Thyago José Arruda Pacheco

ORCID: https://orcid.org/0000-0002-8090-0644

University of Brasilia, Brazil

E-mail: thyagojap@gmail.com

José Athayde Vasconcelos Morais

ORCID: https://orcid.org/0000-0003-3067-4842 University of Brasilia, Brazil

E-mail: joseavmorais@gmail.com

Vanderlene Pinto Brandão

ORCID: https://orcid.org/0000-0002-1957-3883 Faculdade de Ciências da Saúde de Unaí, Brazil E-mail: vanderlene.brandao@facisaunai.edu.br

Marina Lima Rodrigues

ORCID: https://orcid.org/0000-0002-9257-7418 University of Brasilia, Brazil

E-mail: marina-bluee@ hotmail.com

Maria das Neves Martins

ORCID: https://orcid.org/0000-0003-2105-158X Faculdade de Ciências da Saúde de Unaí, Brazil

E-mail: maria.martins@facisaunai.edu.br

Danielle Galdino de Souza

ORCID: https://orcid.org/0000-0003-3432-0769 University of Brasilia, Brazil

E-mail: danielle.galdino@hotmail.com

\begin{abstract}
The application of nanotechnology in several areas of medicine has been promising, however, there are still serious problems, such as in the area of oncology, for example. Although nanoparticles can accumulate 10 times more in tumors, less than $1 \%$ of the injected dose actually reaches the tumor, as they are retained mainly in the liver and spleen. Liver-specific macrophages, called Kupffer cells, are one of the main barriers to the use of nanoparticles for cancer treatment. These Kupffer Cells are part of the Mononuclear Phagocytic System (MPS) and exhibit endocytic activity against materials that pass through the blood and enter the liver. For this reason, Kupffer cells are central to the process of eliminating nanoparticles that cross the body's epithelial barriers. Still, chloroquine can act directly on the MPS, helping the nanoparticles reach their final target. This review addresses the main studies with chloroquine acting in the MPS, which could revolutionize cancer treatment or other biological applications.
\end{abstract}

Keywords: Chloroquine; Mononuclear Phagocyte System; Kupffer Cells; Nanoparticles; Liver.

\section{Resumo}

A aplicação da nanotecnologia em diversas áreas da medicina tem sido promissora, entretanto, ainda há sérios problemas como na área da oncologia, por exemplo. Apesar das nanopartículas poderem se acumular 10 vezes mais em tumores, menos de $1 \%$ da dose injetada atinge de fato o tumor, pois ficam retidas principalmente no fígado e baço. Os macrófagos específicos para o fígado, chamados de células de Kupffer, são uma das principais barreiras no uso de nanopartículas para o tratamento do câncer. Essas Células de Kupffer fazem parte do Sistema Fagocitário Mononuclear (SFM) e exibem atividade endocítica contra os materiais que passam pelo sangue e entram no fígado. Por esse motivo, as células de Kupffer são centrais no processo de eliminação de nanopartículas que atravessam as barreiras epiteliais do corpo. Todavia, a cloroquina pode atuar diretamente no SFM, auxiliando as nanopartículas a chegarem no seu alvo final. Essa revisão aborda os principais estudos com a cloroquina atuando no SFM, o que pode revolucionar o tratamento do câncer ou outras aplicações biológicas.

Palavras-chave: Cloroquina; Sistema fagocitário mononuclear; Macrófagos do fígado; Nanopartículas; Fígado.

\section{Resumen}

La aplicación de la nanotecnología en varias áreas de la medicina ha sido prometedora, sin embargo, aún existen problemas graves como la oncología, por ejemplo. Aunque las nanopartículas pueden acumularse 10 veces más en los 
tumores, menos del $1 \%$ de la dosis inyectada llega realmente al tumor, ya que se retienen principalmente en el hígado y el bazo. Los macrófagos específicos del hígado, llamados células de Kupffer, son una de las principales barreras para el uso de nanopartículas para el tratamiento del cáncer. Estas células de Kupffer son parte del sistema fagocítico mononuclear (SFM) y exhiben actividad endocítica contra materiales que pasan a través de la sangre y entran al hígado. Por esta razón, las células de Kupffer son fundamentales para el proceso de eliminación de las nanopartículas que atraviesan las barreras epiteliales del cuerpo. Sin embargo, la cloroquina puede actuar directamente sobre el SFM, ayudando a las nanopartículas a alcanzar su objetivo final. Esta revisión aborda los principales estudios con cloroquina actuando en el SFM, lo que podría revolucionar el tratamiento del cáncer o otras aplicaciones biológicas.

Palabras clave: Cloroquina; Sistema mononuclear fagocítico; Macrófagos del hígado; Nanopartículas; Hígado.

\section{Introduction}

Chloroquine is a product created between wars, used initially to protect military personnel against malaria, but which civilians were also able to benefit from. Since the 1940s, the Food And Drug Administration (FDA) has approved chloroquine, but until today it is studied for various purposes, whether in the treatment of malaria, lupus, cancer, dengue and, more recently, against the new coronavirus - SARS -VOC-2 (de Souza \& Pacheco, 2020; Hu et al., 2020).

One of the promising applicationsbiological tions of chloroquine is modulation in the immune system to improve delivery of nanoparticles (Pelt et al., 2018). Nanotechnology provides some pharmacological advantages such as: reduction of treatment toxicity, dispersion of insoluble drugs in water, co-delivery and screening of two or more drugs for combined therapy (Ho et al., 2017; Pacheco, 2020). However, a 2016 study showed that less than 1\% of administered nanoparticles were reaching the desired target, representing a major obstacle to better application of Nanobiotechnology (Wilhelm et al., 2016).

The low delivery of nanopartcells in the desired target is largely due to the Mononuclear Phagocytic System (MPS). MPS consists of phagocytic immune cells, such as macrophages, located in different parts of the body. It is these MPS cells that contribute to the greatest loss of injected dose of nanoparticles (dos Santos et al., 2017; Wilhelm et al., 2016). The clearance of nanoparticles occurs via opionization and later lysosomal degradation (dos Santos et al., 2017).

The liver is the main site of metabolism and excretion of endogenous and exogenous agents. It receives blood either via the heart, via the hepatic arteries, or via the gastrointestinal tract, via the hepatic portal vein. Blood from these pathways arrives in the hepatic sinusoids, a region with a large amount of macrophages called Kupffer cells (H. Wang et al., 2015).

As cKupffer cells are important in the innate immune response, protecting the body against possible invaders or foreign molecules, however, this phagocytic clearance pathway is of little interest when the objective is to deliver nanoparticles carrying drugs for the treatment of some disease, as the drug carried can not reaching the desired target, affecting the treatment, in addition to possible unexpected side effects (Bertrand \& Leroux, 2012; Wolfram \& Ferrari, 2019).

Strategies can be used to prepare the immune system to reduce nanoparticle uptake, including: increasing the nanoparticle half-life; modify surfaces, nanoparticle shapes; biological camouflage and even functional saturation or macrophage depletion (Pacheco, 2020; Wolfram \& Ferrari, 2019).

Some studies have shown that chloroquine can modulate MPS and be an excellent strategy.egy of low cost and with greater effectiveness in the treatment of several diseases. This review addresses the main mechanisms of chloroquine and when and how it is being used to modulate MPS.

\section{Methodology}

This is a narrative review using articles indexed in PubMed and Google Scholar to identify all relevant scientific studies based on our study objectives. There was no language restriction. The following keywords were used: "Chloroquine", “Mononuclear Phagocytic System”, "Kupffer Cells", "Nanoparticles” and "Endocytosis” were used between 2010 and 2021. 


\section{Results and Discussion}

Chloroquine is a drug with tolerable safety and known for over 70 years. There are several applications of chloroquine, whether against malaria, lupus, cancer and it was even used against the 2019 Coronavirus Disease - COVID-19 (de Souza \& Pacheco, 2020; Hu et al., 2020).

This drug is a weak base that becomes deprotonated in acidic environments, increasing the $\mathrm{pH}$ of acidic compartments, such as the lysosome involved in MPS endocytosis (J. Wolfram et al., 2017).

Due to the lysosome behaviorchloroquine, is capable of altering lysosomal $\mathrm{pH}$, interrupting an essential process of endocytosis, in which nanoparticles are degraded by MPS. (Hu et al., 2020; Pacheco, 2020; Pelt et al., 2018; Wolfram \& Ferrari, 2019).

The liver is responsible for the clearance of endogenous and exogenous agents, an important defense mechanism. The liver's own morphology allows it to be the main barrier against nanoparticles. Both the hepatic portal vein and the coronary arteries flow into the liver sinusoids, a region largely constituted by macrophages, or Kupffer cells, components of the MPS, however, the pretreatment with chloroquine, via alteration of the lysosomal $\mathrm{pH}$, can temporarily inhibit the endocytosis of liver macrophages, making nanoparticles more bioavailable (Figure 1) (Pacheco, 2020; Pelt et al., 2018).

The lysosome is usually the final compartment of the endocytosis process, which is the most common mechanism for internalization of nanoparticles into cells, however, it has been shown that chloroquine also acts in early stages of endocytosis, such as inhibiting the endocytosis assembly protein called Phosphatidylinositol-binding clathrin (PICALM) (Sahay et al., 2010; Joy Wolfram et al., 2017).

It's interesting to note that the lysosomal modification generated by chloroquine has the potential to act not only against the uptake of nanoparticles by the MPS, but also preventing the entry of viruses into cells by altering the endocytosis process. (Hu et al., 2020; Raftery et al., 2020; L.-F. Wang et al., 2015).

Furthermore, chloroquine it self may also have mechanisms against cancer, such as inhibition of autophagy, activation of apoptosis and normalization of tumor vasculature, so it is applied as an adjuvant therapy in some studies (Joshi et al., 2012; Kimura et al., 2013; Zhang et al., 2015).

Autophagy is a cellular process that involves the elimination and recycling of cytoplasmic components, which can increase cell survival by recycling nutrients and metabolites (Amaravadi et al., 2011; Cicchini et al., 2015; Kuma \& Mizushima, 2010). Cancer cells that perform autophagy can be a problem for the treatment of cancer itself, however chloroquine, by increasing the $\mathrm{pH}$ of the lysosome in autophagy, is able to block cellular autophagy, making tumor cells more susceptible to apoptosis (Amaravadi et al., 2011; Pelt et al., 2018)

Other studies show the potential of chloroquine both in the reduction of metastasis and in the normalization of the tumor vasculature, which improves blood perfusion for better administration of nanocarrier drugs (Maes et al., 2014; Pelt et al., 2018).

Therefore, due to the lysosome behaviorchloroquine, it is able to efficiently modulate MPS, reducing nanoparticle uptake by Kupffer cells, as well as helping with important underlying mechanisms such as autophagy inhibition and tumor vasculature normalization to improve nanoparticle delivery (Pacheco, 2020; Pelt et al., 2018). 
Figure 1 - Mechanism of action of chloroquine in MPS. Chloroquine increases the pH of the MPS macrophage lysosome, affecting endocytosis and increasing the bioavailability of nanoparticles.

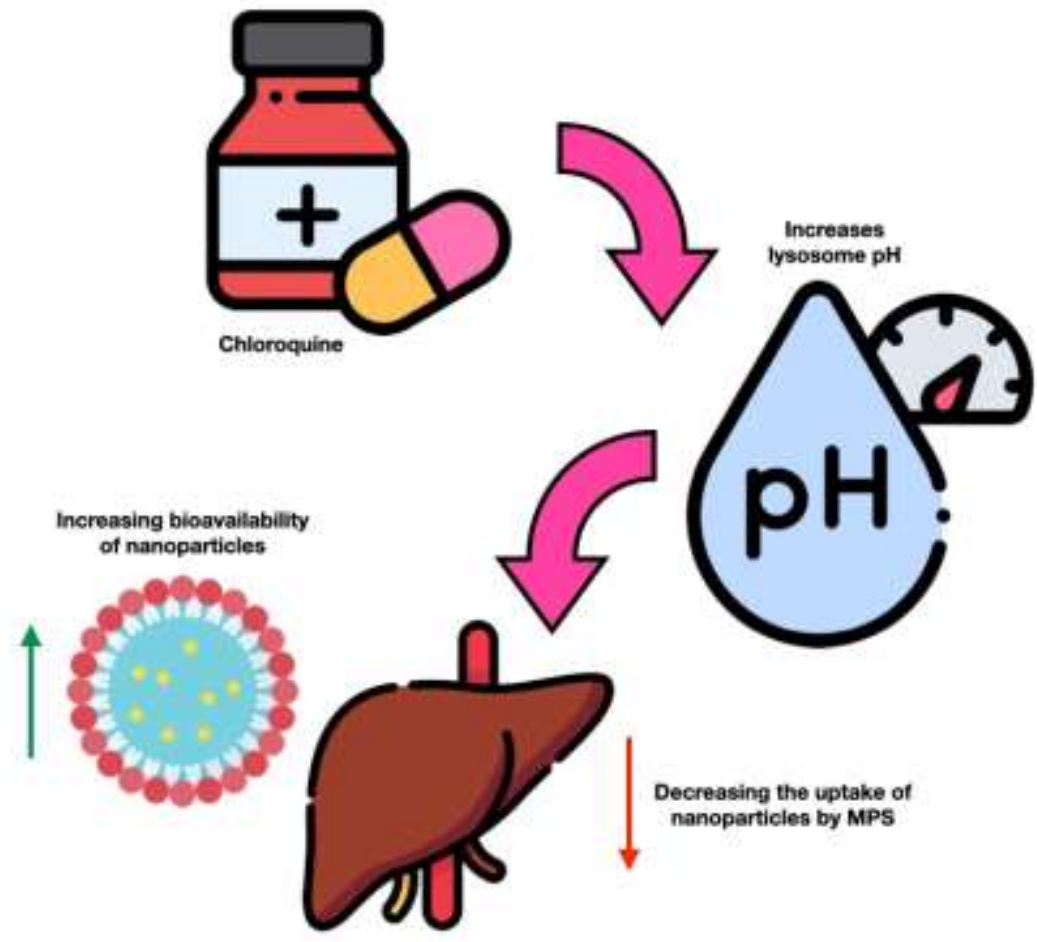

Source: Authors (2021).

\section{Conclusion}

Chloroquine is a drug with tolerable safety approved since the 40's. Several studies show its potential against malaria, lupus, cancer and also in modulating the MPS barrier. Recent studies have shown that chloroquine may be important as a pretreatment in cancer, since, due to its lysosomotropic behavior, it is able to modulate MPS endocytosis, especially in Kupffer cells, making the nanoparticles of interest more bioavailable to be delivered to the desired target. However, more safety and efficacy tests are still needed to validate all these benefits found with chloroquine for various off-label applications.

\section{Acknowledgements}

The authors thank the work of health professionals who are fighting the COVID-19, their efforts will never be forgotten by humanity. We thank the Department of Genetics and Morphology, Institute of Biological Sciences, University of Brasilia (GEM-IB-UnB) for their kind support in providing resources and infrastructure for the study. This work did not receive any specific support, but we would like to thank the funding agencies: the Brazilian National Council for Technological and Scientific Development $(\mathrm{CNPq})$, Coordinating Agency for Advanced Training of Graduate Personnel (CAPES), Foundation for Research Support of the Federal District (FAPDF) and the Dean of Research and Post-Graduation of the University of Brasilia (DPP-UnB).

\section{References}

Amaravadi, R. K., Lippincott-Schwartz, J., Yin, X. M., Weiss, W. A., Takebe, N., Timmer, W., DiPaola, R. S., Lotze, M. T., \& White, E. (2011). Principles and current strategies for targeting autophagy for cancer treatment. Clin Cancer Res, 17(4), 654-666. https://doi.org/10.1158/1078-0432.Ccr-10-2634 
Bertrand, N., \& Leroux, J. C. (2012). The journey of a drug-carrier in the body: an anatomo-physiological perspective. J Control Release, 161(2), 152-163. https://doi.org/10.1016/j.jconrel.2011.09.098

Cicchini, M., Karantza, V., \& Xia, B. (2015). Molecular pathways: autophagy in cancer--a matter of timing and context. Clin Cancer Res, 21(3), 498-504. https://doi.org/10.1158/1078-0432.Ccr-13-2438

de Souza, D. G., \& Pacheco, T. J. A. (2020). Chloroquine in human history. Amazon Digital Services LLC - KDP Print US. https://books.google.com.br/books?id=3PT6zQEACAAJ

dos Santos, S. N., Rezende Dos Reis, S. R., Pires, L. P, Helal-Neto, E., Sancenón, F., Barja-Fidalgo, T. C, Medina de Mattos, R., Nasciutti, L. E, MartínezMáñez, R. , \& Santos-Oliveira, R. (2017). Avoiding the mononuclear phagocyte system using human albumin for mesoporous silica nanoparticle system. Microporous and Mesoporous Materials, 251, 181-189. https://doi.org/https://doi.org/10.1016/j.micromeso.2017.06.005

Ho, B. N., Pfeffer, C. M., \& Singh, A. T. (2017). Update on nanotechnology-based drug delivery systems in cancer treatment. Anticancer research, 37(11), 5975-5981.

Hu, T. Y, Frieman, M., \& Wolfram, J. (2020). Insights from nanomedicine into chloroquine efficacy against COVID-19. Nature nanotechnology, 15(4), 247249.

Joshi, P., Chakraborti, S., Ramirez-Vick, J. E, Ansari, Z. A, Shanker, V., Chakrabarti, P., \& Singh, S. P. (2012). The anticancer activity of chloroquine-gold nanoparticles against MCF-7 breast cancer cells. Colloids and Surfaces B: Biointerfaces, 95, 195-200. https://doi.org/https://doi.o $\mathrm{rg} / 10.1016 / \mathrm{j}$.colsurfb.2012.02.039

Kimura, T., Takabatake, Y., Takahashi, A., \& Isaka, Y. (2013). Chloroquine in cancer therapy: the double-edged sword of autophagy. Cancer research, 73(1), $3-7$.

Kuma, A., \& Mizushima, N. (2010). Physiological role of autophagy as an intracellular recycling system: with an emphasis on nutrient metabolism. Semin Cell Dev Biol, 21(7), 683-690. https://doi.org/10.1016/j.semcdb.2010.03.002

Maes, H., Kuchnio, A., Peric, A., Moens, S., Nys, K., De Bock, K., Quaegebeur, A., Schoors, S., Georgiadou, M., Wouters, J., Vinckier, S., Vankelecom, H., Garmyn, M., Vion, A.-C., Radtke, F., Boulanger, C., Gerhardt, H., Dejana, E., Dewerchin, M., Ghesquière , B., Annaert, W., Agostinis, P., \& Carmeliet, P. (2014). Tumor Vessel Normalization by Chloroquine Independent of Autophagy. Cancer Cell, 26(2), 190-206. https://doi.org/https://doi.org/10.1016/j.ccr.2014.06.025

Pacheco, T. J. A (2020). Modulation of lipid nanoemulsion uptake in the hepatic mononuclear phagocytic system by the action of chloroquine.

Pelt, J., Busatto, S., Ferrari, M., Thompson, E. A, Mody, K., \& Wolfram, J. (2018). Chloroquine and nanoparticle drug delivery: A promising combination. Pharmacol Ther, 191, 43-49. https://doi.org/10.1016/j.pharmthera.2018.06.007

Raftery, M. J, Lalwani, P., Lutteke, N., Kobak, L., Giese, T., Ulrich, R. G, Radosa, L., Kruger, D. H, \& Schonrich, G. (2020). Replication in the Mononuclear Phagocyte System (MPS) as a Determinant of Hantavirus Pathogenicity. Front Cell Infect Microbiol, 10, 281. https://doi.org/10.3389/fcimb.2020.00281

Sahay, G., Alakhova, D. Y., \& Kabanov, A. V (2010). Endocytosis of nanomedicines. J Control Release, 145(3), 182-195. https://doi.org/10.1016/j.jconrel.2010.01.036

Wang, H., Thorling, C. A, Liang, X., Bridle, K. R, Grice, JE, Zhu, Y., Crawford, D. H. G., Xu, ZP, Liu, X., \& Roberts, M. S. (2015). Diagnostic imaging and therapeutic application of nanoparticles targeting the liver [10.1039/C4TB01611D]. Journal of Materials Chemistry B, 3(6), 939-958. https://doi.org/10.1039/C4TB01611D

Wang, L.-F., Lin, Y.-S., Huang, N.-C., Yu, C.-Y., Tsai, W.-L., Chen, J.-J., Kubota, T., Matsuoka, M., Chen, S.-R., \& Yang, C.-S. (2015). Hydroxychloroquine-inhibited dengue virus is associated with host defense machinery. Journal of Interferon \& Cytokine Research, 35(3), 143-156.

Wilhelm, S., Tavares, AJ, Dai, Q., Ohta, S., Audet, J., Dvorak, HF, \& Chan, WCW (2016). Analysis of nanoparticle delivery to tumors. Nature Reviews Materials, 1(5), 16014. https://doi.org/10.1038/natrevmats.2016.14

Wolfram, J., \& Ferrari, M. (2019). Clinical cancer nanomedicine. Nano Today, 25, 85-98. https://doi.org/https://doi.org/10.1016/j.nantod.2019.02.005

Wolfram, J., Nizzero, S., Liu, H., Li, F., Zhang, G., Li, Z., Shen, H., Blanco, E., \& Ferrari, M. (2017). A chloroquine-induced macrophage-preconditioning strategy for improved nanodelivery. Scientific Reports, 7(1), 13738. https://doi.org/10.1038/s41598-017-14221-2

Wolfram, J., Nizzero, S., Liu, H., Li, F., Zhang, G., Li, Z., Shen, H., Blanco, E., \& Ferrari, M. (2017). A chloroquine-induced macrophage-preconditioning strategy for improved nanodelivery. Sci Rep, 7(1), 13738. https://doi.org/10.1038/s41598-017-14221-2

Zhang, Y., Liao, Z., Zhang, L.-j., \& Xiao, H.-t. (2015). The utility of chloroquine in cancer therapy. Current medical research and opinion, $31(5), 1009-1013$. 